\title{
Post-exercise protein synthesis rates are only marginally higher in type I compared with type II muscle fibres following resistance-type exercise
}

\author{
René Koopman • Benjamin G. Gleeson • \\ Annemie P. Gijsen • Bart Groen • Joan M. G. Senden • \\ Michael J. Rennie • Luc J. C. van Loon
}

Received: 20 September 2010/Accepted: 23 December 2010/Published online: 14 January 2011

(C) The Author(s) 2011. This article is published with open access at Springerlink.com

\begin{abstract}
We examined the effect of an acute bout of resistance exercise on fractional muscle protein synthesis rates in human type I and type II muscle fibres. After a standardised breakfast (31 $\pm 1 \mathrm{~kJ} \mathrm{~kg}^{-1}$ body weight, consisting of 52 Energy\% (En\%) carbohydrate, 34 En\% protein and 14 En\% fat), 9 untrained men completed a lower-limb resistance exercise bout ( 8 sets of 10 repetitions leg press and leg extension at $70 \% 1 \mathrm{RM})$. A primed, continuous infusion of L-[ring- ${ }^{13} \mathrm{C}_{6}$ ]phenylalanine was combined with muscle biopsies collected from both legs immediately after exercise and after 6 h of post-exercise recovery. Single muscle fibres were dissected from freeze-dried biopsies and stained for ATPase activity with pre-incubation at a $\mathrm{pH}$ of 4.3. Type I and II fibres were separated under a light microscope and analysed for protein-bound $\mathrm{L}-\left[\mathrm{ring}-{ }^{13} \mathrm{C}_{6}\right]$ phenylalanine
\end{abstract}

Communicated by Håkan Westerblad.

R. Koopman · B. G. Gleeson · A. P. Gijsen · B. Groen ·

J. M. G. Senden · L. J. C. van Loon ( $₫)$

Department of Human Movement Sciences, NUTRIM School

for Nutrition, Toxicology and Metabolism, Maastricht

University Medical Centre, PO Box 616,

6200 MD Maastricht, The Netherlands

e-mail: 1.vanloon@hb.unimaas.nl

M. J. Rennie

School of Graduate Entry Medicine and Health,

Derby City Hospital, University of Nottingham,

Uttoxeter Road, Derby DE22 3DT, UK

Present Address:

R. Koopman · B. G. Gleeson

Basic and Clinical Myology Laboratory, The University

of Melbourne, Melbourne, VIC 3010, Australia labelling. Baseline (post-exercise) L-[ring- ${ }^{13} \mathrm{C}_{6}$ ]phenylalanine muscle tissue labelling, expressed as $\left(\partial^{13} \mathrm{C} /{ }^{12} \mathrm{C}\right)$, averaged $-32.09 \pm 0.28,-32.53 \pm 0.10$ and $-32.02 \pm 0.16$ in the type I and II muscle fibres and mixed muscle, respectively $(P=0.14)$. During post-exercise recovery, muscle protein synthesis rates were marginally $(8 \pm 2 \%)$ higher in the type I than type II muscle fibres, at $0.100 \pm 0.005$ versus $0.094 \pm 0.005 \% / \mathrm{h}$, respectively $(P<0.05)$, whereby rates of mixed muscle protein were $0.091 \pm 0.005 \% / \mathrm{h}$. Muscle protein synthesis rates following resistance-type exercise are only marginally higher in type I compared with type II muscle fibres.

Keywords Skeletal muscle $\cdot$ Muscle fibre type - ATPase · FSR · Stable isotopes

\section{Introduction}

In humans, changes in muscle protein synthesis (MPS) and breakdown in response to food intake and/or exercise are normally assessed in vastus lateralis muscle (Rennie et al. 1982). In rats, mice, cats and dogs, lagomorphs rates of MPS are markedly different between different muscle groups (Garlick et al. 1989). However, it is generally assumed that the metabolic behaviour of skeletal muscle tissue is the same throughout the human body and that results obtained in quadriceps muscle can be extrapolated to total skeletal muscle and, as such, whole-body protein turnover (Mittendorfer et al. 2005). As no significant correlations have been observed between type I muscle fibre content and the measured muscle protein fractional synthetic rates of triceps, soleus and vastus lateralis, it was concluded that differences in basal, resting muscle protein synthesis rates between muscle groups are 
relatively small $(<15 \%)$ and of minor biological significance (Mittendorfer et al. 2005). However, interesting new data has emerged suggesting that resting muscle protein synthesis rates are substantially $(\sim 30 \%)$ higher in type I compared to type II muscle fibres (Dickinson et al. 2010). So far, almost no data are available on potential fibre type specific differences in the muscle protein synthetic response to anabolic stimuli such as food intake and/or exercise.

Rates of MPS increase rapidly following a single bout of resistance-type exercise (Phillips et al. 1997), and remain elevated for up to $24-48 \mathrm{~h}$ if the subjects are fed during post-exercise recovery (MacDougall et al. 1992; Phillips et al. 1997; Tang et al. 2008). It has been speculated that the muscle protein synthetic response to resistance-type exercise is fibre type specific (Koopman et al. 2006c; Mittendorfer et al. 2005; Trappe et al. 2004). In accordance with this hypothesis, we showed that muscle fibre hypertrophy after 12 weeks of resistance exercise training is restricted to the type II muscle fibres in human vastus lateralis tissue of elderly men (Verdijk et al. 2009). In addition, it has been reported that a predominantly oxidative fibred muscle (soleus) has a smaller hypertrophic response to resistance exercise than vastus lateralis muscle (Trappe et al. 2004). In agreement, the phosphorylation status of key-regulatory proteins involved in the activation of protein synthesis (i.e. PKB (or Akt), mTOR and S6K1) seems to be more pronounced in muscle tissue containing a greater proportion of type II muscle fibres following resistance-type exercise in rats (Baar and Esser 1999; Parkington et al. 2003; Sakamoto et al. 2003). The latter was confirmed recently by our observation that $\mathrm{S} 6 \mathrm{~K} 1$ (at the $\mathrm{T}^{421} / \mathrm{S}^{424}$ phosphorylation sites) is phosphorylated in a fibre type dependent manner after a single bout of resistance exercise (Koopman et al. 2006c). These findings suggested that rates of MPS may be higher in type II than type I fibres after resistance exercise. However, so far no direct measurements of rates of MPS in human type I and II have been reported after exercise.

We hypothesised that MPS rates would be greater in type II than type I muscle fibres after a single session of resistance exercise. To test this, we conducted studies involving continuous infusions of L-[ring- ${ }^{13} \mathrm{C}_{6}$ ]phenylalanine combined with muscle biopsies taken immediately after a single bout of resistance exercise and after $6 \mathrm{~h}$ of post-exercise recovery. A modified ATPase staining procedure for freeze-dried muscle fibres was applied to differentiate between type I and II muscle fibres, allowing us to assess MPS rates in mixed muscle and in separated type I and II muscle fibres during post-exercise recovery.

\section{Methods}

Subjects

Nine healthy, male volunteers (Table 1) who did not participate in any regular exercise program (nor had done previously) were recruited to participate in the present study. All subjects were informed about the nature and possible risks of the procedures, before written consent was obtained. This study was approved by the Medical Ethics Committee of the Academic Hospital Maastricht, according to the Helsinki Declaration. All volunteers were instructed to refrain from any exhausting physical activity and to consume a normal diet for 3 days prior to the study.

\section{Pretesting}

Body composition was assessed by hydrostatic weighing in the morning after an overnight fast as described previously (Koopman et al. 2006c). Thereafter, maximum leg strength was estimated using multiple repetitions of leg extensions. In an additional exercise session, at least 1 week before the first visit, the subjects' one-repetition maximum (1-RM) was determined (Kraemer and Fry 1995).

\section{Protocol}

On the evening before the study day, subjects consumed a standard meal $\left(32 \pm 2 \mathrm{~kJ} \mathrm{~kg}^{-1}\right.$ body weight, consisting of 55 Energy\% (En\%), carbohydrate, 25 En\% protein and 30 En\% fat). At 08.00, after an overnight fast, subjects arrived at the laboratory by car or public transportation. A Teflon cannula was inserted into an antecubital vein for stable isotope infusion. A second cannula was inserted into a dorsal vein of the contra-lateral hand, and the hand was placed in a hot-box $\left(60^{\circ} \mathrm{C}\right)$ for arterialized blood sampling. After basal blood sample collection $(t=-125 \mathrm{~min})$, subjects consumed a standardised breakfast $\left(31 \pm 1 \mathrm{~kJ} \mathrm{~kg}^{-1}\right.$

Table 1 Subjects' characteristics

\begin{tabular}{lc}
\hline & Subjects \\
\hline Age (years) & $21.8 \pm 0.8$ \\
Weight $(\mathrm{kg})$ & $80.4 \pm 2.4$ \\
Height $(\mathrm{m})$ & $1.89 \pm 0.02$ \\
BMI $\left(\mathrm{kg} \mathrm{m}^{-2}\right)$ & $22.6 \pm 0.8$ \\
$\%$ Body fat (\%) & $13.7 \pm 2.4$ \\
Leg volume (L) & $9.8 \pm 0.4$ \\
1RM leg press (kg) & $242 \pm 10$ \\
1RM leg extension $(\mathrm{kg})$ & $146 \pm 5$ \\
\hline
\end{tabular}

Values are expressed as means $\pm \operatorname{SEM}(n=9) .1 R M$ one-repetition maximum 
body weight, consisting of 52 En\% carbohydrate, 34 En\% protein and $14 \mathrm{En} \%$ fat). Thereafter, at $t=-120 \mathrm{~min}$, a dose of $\mathrm{L}-\left[\right.$ ring- ${ }^{13} \mathrm{C}_{6}$ ]phenylalanine $\left(2 \mu \mathrm{mol} \mathrm{kg}{ }^{-1}\right.$, Cambridge Isotope laboratories, Andover, MA, USA) was administered to prime the phenylalanine pool, whereupon, a continuous tracer infusion of $0.049 \pm 0.001 \mu \mathrm{mol} \mathrm{kg}{ }^{-1}$. $\min ^{-1}$ was started. Subjects rested in a supine position for $1 \mathrm{~h}$ after which another blood sample was collected $(t=$ $-60 \mathrm{~min}$ ) just before subjects engaged in the resistancetype exercise bout, i.e. $1 \mathrm{~h}$ after ingestion of the breakfast. After a 5 min warm-up on a cycle ergometer $(\sim 75 \mathrm{~W})$, the subjects completed a session of 8 sets of 10 repetitions each of leg press and extension (Technogym BV, Rotterdam, The Netherlands), at $70 \%$ of their individual 1-RM, with 2 min rest between sets. All subjects were encouraged during exercise and the entire exercise protocol required $\sim 45 \mathrm{~min}$. At the end of exercise $(t=0 \mathrm{~min})$, subjects rested supine and an arterialized blood sample and muscle biopsies from the vastus lateralis of each leg were collected. Arterialized blood samples were collected at $t=60,120,180,240,300$, and $360 \mathrm{~min}$ with muscle biopsies taken from each leg at $t=360 \mathrm{~min}$ from a new incision. Biopsies (200 mg) were obtained from the middle region of the vastus lateralis muscle $(\sim 15 \mathrm{~cm}$ above the patella) and $\sim 3 \mathrm{~cm}$ below the skin through the fascia using a percutaneous needle (Bergstrom 1975). Muscle samples were dissected, freed from any visible non-muscle material, immediately frozen in liquid nitrogen and stored at $-80^{\circ} \mathrm{C}$ until analysis. Blood was collected in EDTA containing tubes and centrifuged at $1000 \times g$ for $5 \mathrm{~min}$ at $4^{\circ} \mathrm{C}$. Aliquots of plasma were frozen in liquid nitrogen and stored at $-80^{\circ} \mathrm{C}$ until analyses.

\section{Plasma sample analyses}

For plasma phenylalanine labelling measurements, plasma phenylalanine was derivatized using a t-butyldimethylsilyl (TBDMS) whose ${ }^{13} \mathrm{C}$ labelling was determined by electron ionisation gas chromatography-mass spectrometry (GC-MS, Agilent 6890 N GC/5973 N MSD Little Falls, USA) using selected ion monitoring of masses 336 and 342 for unlabelled and labelled L-[ring- ${ }^{13} \mathrm{C}_{6}$ ]phenylalanine, respectively (Koopman et al. 2005). We applied standard regression curves in all isotopic enrichment analysis to assess linearity of the mass spectrometer and to control for loss of tracer.

Muscle sample analyses

\section{Selection of type I and II muscle fibres using modified ATPase staining}

For measurement of protein-bound L- ring- $_{-}{ }^{13} \mathrm{C}_{6}$ ]phenylalanine labelling in the type I and II muscle fibres, $\sim 200 \mathrm{mg}$ wet muscle tissue was freeze-dried. Collagen, blood and other non-muscle fibre material were removed from the muscle, and individual muscle fibres were separated under a light microscope. The isolated muscle fibres were stained for ATPase activity using a modified staining procedure for histochemical applications (Mabuchi and Sreter 1980a, b). Briefly, isolated muscle fibres were placed in an Eppendorf tube and pre-incubated at room temperature (RT) at $\mathrm{pH} 4.3$, washed with Tris-based buffer $(\mathrm{pH} 7.8)$ and distilled water, and subsequently incubated in ATP containing glycine buffer ( $\mathrm{pH} \mathrm{9.4)} \mathrm{for} 25 \mathrm{~min}$ at RT. Thereafter, fibres were washed with $1 \%$ calcium chloride, distilled water, and $1 \%$ cobalt chloride, and type I and II fibres were stained black and white, respectively, using an ammonium sulphide solution in the Eppendorf tubes at RT. Type I and II muscle fibres were separated under a light microscope (Fig. 1) and transferred to separate vials. We separated $3.3 \pm 0.2 \mathrm{mg}$ type I fibres (range: 1.9-4.3 mg wet weight), and $3.5 \pm$ $0.2 \mathrm{mg}$ type II fibres (range: $2.0-4.6 \mathrm{mg}$ wet weight). After adding ice-cold 2\% perchloric acid (PCA) the muscle fibres were homogenised and centrifuged. Protein pellets were further processed to determine protein-bound L-[ring- ${ }^{13} \mathrm{C}_{6}$ ]phenylalanine labelling as described below.

\section{Measurement of free and protein-bound L-[ring- $\left.{ }^{13} C_{6}\right]$ phenylalanine enrichment}

For measurement of precursor (tissue free amino acid pool) and protein-bound (mixed muscle protein) L-[ring- ${ }^{13} \mathrm{C}_{6}$ ] phenylalanine labelling, $50 \mathrm{mg}$ of muscle was freeze-dried and non-muscle fibre material removed under a light microscope. The isolated muscle fibre mass $(\sim 10 \mathrm{mg})$ was weighed and eight volumes $(\sim 8 \times$ dry weight of isolated muscle fibres $\times$ wet/dry ratio) of PCA was added. After

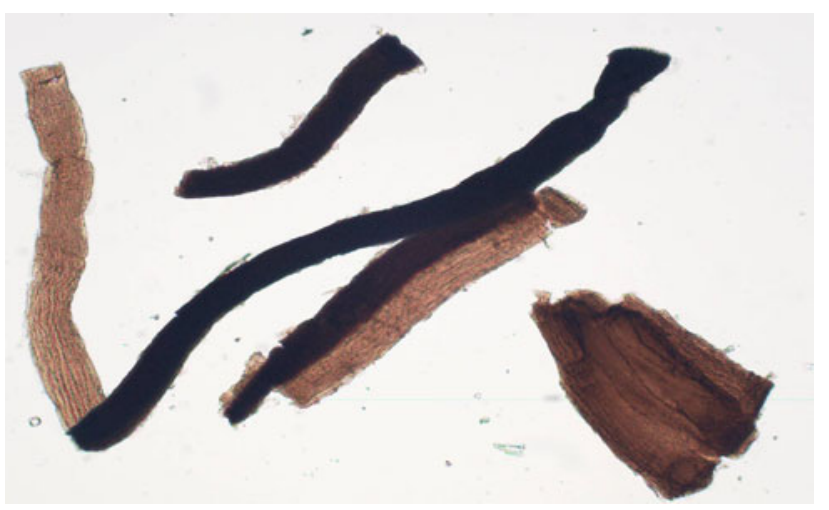

Fig. 1 Separation of type I and II muscle fibres using a modified ATPase staining procedure to allow muscle fibre type specific assessment of L-[ring- ${ }^{13} \mathrm{C}_{6}$ ]phenylalanine incorporation into muscle protein. Collagen, blood and other non-muscle fibre material were removed from the muscle fibres, and individual muscle fibres were separated. Following the modified ATPase staining, type I (black) and II (white/grey) muscle fibres were separated under a light microscope 
homogenisation and centrifugation the supernatant was collected and processed in the same manner as plasma so that tissue free $\mathrm{L}-\left[\right.$ ring- ${ }^{13} \mathrm{C}_{6}$ ]phenylalanine labelling could be measured (Koopman et al. 2005). We did not differentiate between intra- and extracellular free $\mathrm{L}$-[ring- ${ }^{13} \mathrm{C}_{6}$ ] phenylalanine labelling and as free phenylalanine concentrations did not differ between type I and II muscle fibres (Blomstrand and Essen-Gustavsson 2009), it was assumed that free $\mathrm{L}$-[ring ${ }^{13} \mathrm{C}_{6}$ ]phenylalanine labelling is also similar in both fibre types.

The protein pellet, of type I, II and mixed muscle fibres, was washed with 3 additional $1.5 \mathrm{ml}$ washes of $2 \%$ PCA, dried and the proteins hydrolysed in $6 \mathrm{M} \mathrm{HCl}$ at $120^{\circ} \mathrm{C}$ for 15-18 $\mathrm{h}$. The hydrolysed protein fraction was dried under a nitrogen stream while heated to $120^{\circ} \mathrm{C}$, then dissolved in a $50 \%$ acetic acid solution, and passed over a Dowex resin (AG $50 \mathrm{~W}-\mathrm{X} 8,100-200$ mesh $^{+}$form, Biorad, Hercules, CA, USA) using $2 \mathrm{M} \mathrm{NH}_{4} \mathrm{OH}$. Thereafter, the eluate was dried and the purified amino acids were derivatized as their $N(O, S)$-ethoxycarbonyl ethyl esters for the determination of ${ }^{13} \mathrm{C}^{12} \mathrm{C}$ ratios of muscle protein-bound phenylalanine (Koopman et al. 2007a), by gas chromatography-isotope ratio mass spectrometry (GC-IRMS, Finnigan MAT 252, Bremen, Germany) using HP Ultra I GC-column (\#19091A112, Hewlett-Packard, Palo. Alto, CA), combustion interface II and monitoring of ion masses 44, 45 and 46. By establishing the relationship between the labelling of a series of L-[ring- ${ }^{13} \mathrm{C}_{6}$ ]phenylalanine standards of variable enrichment and the enrichment of the $N(O, S)$-ethoxycarbonyl ethyl esters of these standards, the muscle protein-bound labelling of phenylalanine was determined. We applied standard regression curves to assess linearity of the mass spectrometer and to control for the loss of tracer. The coefficient of variance $(\mathrm{CV})$ for the measurement of $\mathrm{L}$-[ring- $\left.{ }^{13} \mathrm{C}_{6}\right]$ phenylalanine enrichment in mixed muscle protein averaged $1.0 \pm 0.1 \%$.

\section{Calculations}

The plasma, tissue free and protein-bound L-[ring- ${ }^{13} \mathrm{C}_{6}$ ] phenylalanine labelling is presented as tracer (L-[ring- ${ }^{13} \mathrm{C}_{6}$ ] phenylalanine)/tracee (unlabelled phenylalanine) ratio (TTR). The fractional rate of mixed muscle protein synthesis (FSR) during post-exercise recovery was calculated by dividing the increment in enrichment in the product, i.e. protein-bound $\mathrm{L}$-[ ring $-{ }^{13} \mathrm{C}_{6}$ ]phenylalanine in type $\mathrm{I}$ and type II muscle fibres and in mixed muscle protein, by the enrichment of the precursor, [i.e. plasma or tissue free L-[ring- ${ }^{13} \mathrm{C}_{6}$ ]phenylalanine labelling (Koopman et al. 2005)]. As it has been recently shown that free phenylalanine concentrations do not differ between type I and II muscle fibres (Blomstrand and Essen-Gustavsson 2009), it seems reasonable to assume that free $\mathrm{L}$-[ring- ${ }^{13} \mathrm{C}_{6}$ ] phenylalanine labelling is also similar in both fibre types. As such, we have used plasma and tissue free $\mathrm{L}-\left[\mathrm{ring}_{-}{ }^{13} \mathrm{C}_{6}\right.$ ] phenylalanine labelling as precursor for the determination of muscle fibre type specific protein synthesis rates, as described previously (Dickinson et al. 2010).

\section{Statistics}

The present study was designed to assess muscle fibre type specific protein synthesis rates during post-exercise recovery. All data are expressed as means \pm SEM. Calculation of the required sample size was based on effect size and variance in previous studies from our laboratory (Koopman et al. 2005, 2006b, 2007a, 2008, 2009). We calculated sample size using the following parameters: difference in FSR $15 \%$, SD of $10 \%$, with type I error of $5 \%$ and type II error of $10 \%$. Power calculations showed that at least 8 participants were needed and we therefore included nine men in this study. A Student paired $t$ test was applied to test for differences in protein synthesis rates between type I and II fibres types. A one-way ANOVA was applied to test whether there were any differences in protein-bound labelling and protein synthesis between mixed muscle and the different fibre types. Statistical significance was set at $P<0.05$. All calculations were performed using StatView 5.0 (SAS Institute inc., Cary, NC, USA).

\section{Results}

\section{Resistance exercise}

Individual one-repetition maximum strength (1RM) measured during the pre-test averaged $242 \pm 10 \mathrm{~kg}$ (horizontal leg press) and $146 \pm 5 \mathrm{~kg}$ (leg extension). Therefore, average weight lifted during the resistance exercise session was set at $181 \pm 7$ and $110 \pm 4 \mathrm{~kg}$ for the leg press and leg extension, respectively. All subjects completed 8 sets with 10 repetitions on the leg press and the leg extension.

Plasma and tissue free phenylalanine labelling

Plasma L-[ring- ${ }^{13} \mathrm{C}_{6}$ ]phenylalanine labelling increased over time and remained stable during the last $3 \mathrm{~h}$ of post-exercise recovery (Fig. 2). During $6 \mathrm{~h}$ of post-exercise recovery, plasma L-[ring $-{ }^{13} \mathrm{C}_{6}$ ]phenylalanine labelling averaged $0.070 \pm 0.002$ (TTR). Muscle tissue free L-[ring- ${ }^{13} \mathrm{C}_{6}$ ] phenylalanine labelling increased over time, averaging $0.046 \pm 0.002$ and $0.061 \pm 0.001$ (TTR) in the biopsy samples taken immediately after exercise and after $6 \mathrm{~h}$ of post-exercise recovery, respectively $(P<0.05)$. 
Muscle protein-bound labelling

Basal (post-exercise) muscle protein-bound L-[ring- ${ }^{13} \mathrm{C}_{6}$ ] phenylalanine enrichment $\left(\partial^{13} \mathrm{C} /{ }^{12} \mathrm{C}\right)$ in mixed muscle averaged $-32.02 \pm 0.16$, whereas basal protein-bound L-[ring- ${ }^{13} \mathrm{C}_{6}$ ]phenylalanine labelling averaged $-32.09 \pm$ 0.28 and $-32.53 \pm 0.10$ in type I and II muscle fibres, respectively. No differences were observed between mixed muscle and the different fibre types $(P=0.14)$. During $6 \mathrm{~h}$ of post-exercise recovery, the increase in $\mathrm{L}$-[ ring ${ }^{13} \mathrm{C}_{6}$ ] phenylalanine labelling in mixed muscle protein averaged $0.000291 \pm 0.000011$ (TTR). The increase in proteinbound $\mathrm{L}$-[ring $-{ }^{13} \mathrm{C}_{6}$ ]phenylalanine labelling was marginally, albeit statistically higher in the type I versus type II muscle fibres $(0.000308 \pm 0.000007$ vs. $0.000286 \pm$ 0.000010 (TTR), respectively: $P<0.01$ ).

Muscle protein synthesis

Rates of mixed MPS during post-exercise recovery averaged $0.069 \pm 0.0038 \% / \mathrm{h}$ when calculated using plasma free $\mathrm{L}-\left[\right.$ ring- ${ }^{13} \mathrm{C}_{6}$ ]phenylalanine labelling as precursor. Muscle protein FSR after exercise was significantly higher in type I compared with type II fibres and averaged $0.070 \pm 0.003$ and $0.068 \pm 0.003 \% / \mathrm{h}$, respectively $(P<0.01)$. When muscle protein FSR was calculated with the average muscle tissue free $\mathrm{L}-\left[\right.$ ring $-{ }^{13} \mathrm{C}_{6}$ ]phenylalanine labelling as the precursor pool, similar results were obtained. Mixed muscle protein synthetic rates during the post-exercise recovery averaged $0.091 \pm 0.005 \% / \mathrm{h}$. Muscle protein synthesis rates were $8 \pm 2 \%$ higher in

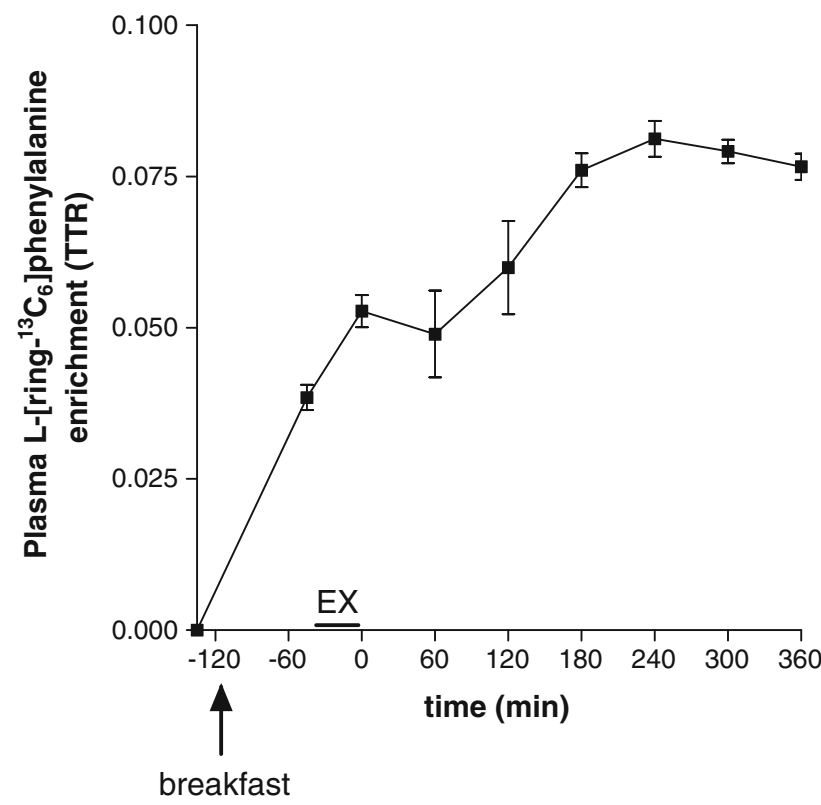

Fig. 2 Plasma L-[ring $-{ }^{13} \mathrm{C}_{6}$ ]phenylalanine enrichments at rest, during exercise and subsequent recovery. Data provided are means \pm SEM type I than type II muscle fibres (Fig. $3, P<0.05$ ), at $0.100 \pm 0.005$ and $0.093 \pm 0.005 \% / \mathrm{h}, \quad$ respectively $(P<0.01)$.

\section{Discussion}

We have previously shown that the phosphorylation status of S6K1 $\left(\mathrm{T}^{421} / \mathrm{S}^{424}\right)$ increases to a greater (30\%) extent in the type II versus type I muscle fibres after resistance-type exercise (Koopman et al. 2006c). In addition, we have reported that muscle hypertrophy after a 12 week RET program is specific in increasing type II muscle fibre size in elderly men (Verdijk et al. 2009). Therefore, we hypothesised that muscle protein synthesis rates would be higher in type II than in type I muscle fibres during the acute stages of post-exercise recovery. We measured muscle protein synthetic rates after resistance exercise in type I and II muscle fibres from human vastus lateralis muscle. To the best of our knowledge, this study is the first to compare MPS rates in type I and II muscle fibres following resistance-type exercise within a single muscle. Fractional muscle protein synthetic rates during post-exercise recovery were $8 \%$ higher in the type I compared with the type II muscle fibres.

Recently published data suggest that MPS in human vastus lateralis muscle is markedly (33\%) higher in type I compared with type IIa muscle fibres following an

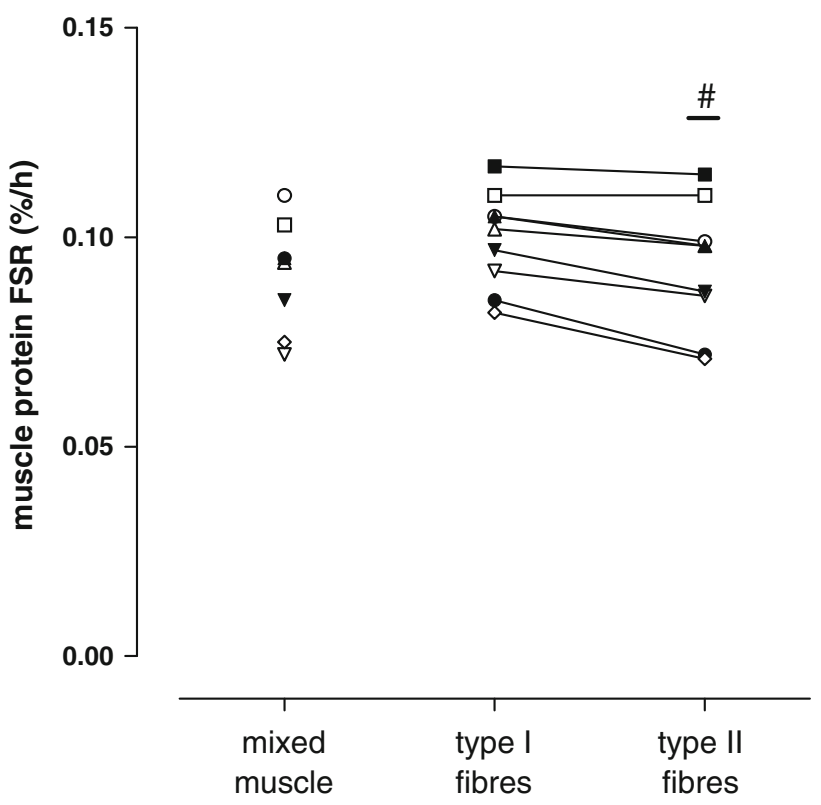

Fig. 3 Individual muscle protein fractional synthetic rates (FSR) during $6 \mathrm{~h}$ of post-exercise recovery in mixed muscle and in separated type I and II muscle fibres. "Significantly different between the type I versus type II muscle fibres, $P \leq 0.05$. No differences between mixed muscle FSR and type I or II muscle fibre FSR 
overnight fast (Dickinson et al. 2010). We extend on these data by assessing muscle fibre type specific protein synthesis rates following resistance-type exercise. We measured protein-bound $\mathrm{L}$-[ring- ${ }^{13} \mathrm{C}_{6}$ ]phenylalanine labelling in type I and II muscle fibres dissected (and stained for ATPase activity) from freeze-dried muscle biopsies collected immediately after cessation of exercise and again after $6 \mathrm{~h}$ of post-exercise recovery. We did not observe any differences in protein-bound L-[ring- ${ }^{13} \mathrm{C}_{6}$ ]phenylalanine labelling between the different muscle fibre types immediately after cessation of exercise. Although we did not aim to assess basal/resting rates of fibre type specific MPS, the lack of difference in protein-bound enrichment between muscle fibre types in biopsies taken immediately after cessation of exercise strongly suggests that MPS rates in the fed state (at rest and during exercise) do not differ between the type I and type II muscle fibres, as suggested by previous work on muscles composed of predominantly one of the fibre types (Mittendorfer et al. 2005). During the $6 \mathrm{~h}$ post-exercise recovery period, protein-bound L-[ring- ${ }^{13} \mathrm{C}_{6}$ ]phenylalanine enrichments increased to a greater extend in the type I compared with the type II muscle fibres $(P<0.01)$. Muscle protein synthesis rates were $8 \pm 2 \%$ higher in type I compared with type II muscle fibres following resistance-type exercise (Fig. 3, $P<0.01$ ). Consequently, our data indicate that muscle protein synthesis rates are only marginally higher in type I compared with type II muscle fibres during recovery following resistance-type exercise.

To be able to determine muscle fibre type specific muscle protein synthesis rates, we collected as much as 200-250 mg muscle tissue to have sufficient tissue available to adequately detect protein-bound L-[ring $-{ }^{13} \mathrm{C}_{6}$ ] phenylalanine enrichment both in mixed muscle and in specifically prepared type I and II muscle fibres. This required us to take biopsies from both legs at each timepoint, restricting the total number of time points where biopsies could be collected. Furthermore, as muscle fibre type specific protein synthesis rates following an overnight fast have been reported previously (Dickinson et al. 2010), we did not assess basal MPS rates. Muscle sample preparation requires separation of each individual muscle fibre, followed by ATPase staining, and subsequent separation of the type I (black) and II (white/grey) muscle fibres (Fig. 1) until sufficient (2-4 mg dry weight) fibres are separated to allow accurate detection of protein-bound L-[ring- ${ }^{13} \mathrm{C}_{6}$ ] phenylalanine labelling using GC-IRMS. The coefficient of variance $(\mathrm{CV})$ of the measurements of protein-bound L-[ring $-{ }^{13} \mathrm{C}_{6}$ ]phenylalanine labelling in the type I and type II muscle fibres was similar to the CV $(\sim 1 \%)$ we normally observe for mixed muscle tissue samples. We must, however, recognise that it is theoretically possible that there are small (short lived) differences in MPS rates within the $6 \mathrm{~h}$ recovery period from exercise, which might not have been detected by the applied protocol. Short-lived responses of feeding and resistance exercise on MPS have previously been observed (Rennie et al. 2002; Kumar et al. 2009). However, given the lack of evidence of significant differences in the feeding responses of MPS in muscles containing predominantly type 1 or type 2 muscle fibres (Mittendorfer et al. 2005) made over a $3 \mathrm{~h}$ period, this seems unlikely.

The observation that type II muscle fibres do not show a greater post-exercise muscle protein synthesis rates when compared with the type I muscle fibres seems to be at odds with previous findings from our laboratory (Koopman et al. 2006c) as well as others (Tannerstedt et al. 2009). Tannerstedt et al. (2009) have recently shown that the phosphorylation status of S6K1 $\left(\mathrm{T}^{389}\right)$ and S6 (but not Akt and mTOR) are increased to a greater extend in type II compared with type I fibres following maximal lengthening contractions. These data are in line with our previous findings that S6K1 phosphorylation at $\mathrm{T}^{421} / \mathrm{S}^{424}$ increases to a greater extend in type II compared with type I fibres following resistance exercise (when exercise is performed in the fasted state) (Koopman et al. 2006c). The latter suggests that the anabolic response to resistance-type exercise is greater in the type II versus type I muscle fibres. We will highlight a few mechanisms that may explain the described discrepancy between our protein synthesis rates and previously published signalling data.

Glycogen utilisation during resistance-type exercise is higher in type II than in type I muscle fibres (Koopman et al. 2006c). AMP-activated protein kinase (AMPK) has a glycogen-binding domain (Sakamoto et al. 2004), and has been shown to be substantially activated when muscle glycogen concentrations are low (Wojtaszewski et al. 2003). Therefore, it could be speculated that AMPK activity is increased to a greater extend in type II than in type I fibres during/following resistance exercise. As a result, the rise in 4E-BP1 phosphorylation (Dreyer et al. 2006; Drummond et al. 2008; Koopman et al. 2006c), and MPS could be more attenuated specifically in type II muscle fibres following exercise. In addition, synthesis rates of myofibrillar and mitochondrial protein are increased following a single session of resistance-type exercise (Wilkinson et al. 2008). As muscle fibre mitochondrial content is up to 2-fold higher in type I versus II muscle fibres (Koopman et al. 2006a) and mitochondrial protein synthesis rates are $\sim 50 \%$ higher than that of myofibrillar protein (Wilkinson et al. 2008) it can be speculated that the observed small differences in postexercise mixed muscle protein FSR between fibre types are due to differences in mitochondrial protein content/turnover. Alternatively, the fact that we observed only marginal differences between fibre types may also be attributed to 
the fact that food was ingested prior to exercise. Free phenylalanine concentrations do not differ between type I and II muscle fibres prior to exercise and during postexercise recovery (Blomstrand and Essen-Gustavsson 2009), suggesting that amino acid-induced changes in muscle protein synthesis are similar between fibre types. In line with these observations, we have shown that S6 phosphorylation increases to a similar extend in both type I and II muscle fibres during post-exercise recovery when food is ingested prior to and/or after exercise (Koopman et al. 2007b).

As recent studies have highlighted the discrepancies between anabolic signalling and muscle protein synthesis (Greenhaff et al. 2008), it is apparent that studies are warranted that investigate fibre type specific muscle protein synthesis at rest and following exercise with and without food intake using contemporary stable isotope methodology (i.e. using ${ }^{13} \mathrm{C}$-labelled phenylalanine). To the best of our knowledge, our study is the first to compare muscle protein synthesis rates in type I and II muscle fibres within one specific muscle group, showing that post-exercise muscle protein synthesis rates are only marginally higher in type I compared with type II muscle fibres. Based on the minor differences between muscle protein synthesis rates in the type I versus type II muscle fibres, it seems reasonable to rely on the measurement of mixed muscle protein synthesis rates when aiming to study the combined effects of physical activity and food intake on muscle protein synthesis.

Acknowledgments We gratefully acknowledge the enthusiastic support of the subjects who volunteered to participate in these experiments. R. Koopman was supported with an International Training Fellowship from the Nutricia Research Foundation, the Netherlands (2006-T4).

Open Access This article is distributed under the terms of the Creative Commons Attribution Noncommercial License which permits any noncommercial use, distribution, and reproduction in any medium, provided the original author(s) and source are credited.

\section{References}

Baar K, Esser K (1999) Phosphorylation of p70(S6k) correlates with increased skeletal muscle mass following resistance exercise. Am J Physiol 276:C120-C127

Bergstrom J (1975) Percutaneous needle biopsy of skeletal muscle in physiological and clinical research. Scand J Clin Lab Invest 35:609-616

Blomstrand E, Essen-Gustavsson B (2009) Changes in amino acid concentration in plasma and type I and type II fibres during resistance exercise and recovery in human subjects. Amino Acids 37:629-636

Dickinson JM, Lee JD, Sullivan BE, Harber MP, Trappe SW, Trappe TA (2010) A new method to study in vivo protein synthesis in slow- and fast-twitch muscle fibers and initial measurements in humans. J Appl Physiol 108:1410-1416

Dreyer HC, Fujita S, Cadenas JG, Chinkes DL, Volpi E, Rasmussen BB (2006) Resistance exercise increases AMPK activity and reduces $4 \mathrm{E}-\mathrm{BP} 1$ phosphorylation and protein synthesis in human skeletal muscle. J Physiol 576:613-624

Drummond MJ, Dreyer HC, Pennings B, Fry CS, Dhanani S, Dillon EL, Sheffield-Moore M, Volpi E, Rasmussen BB (2008) Skeletal muscle protein anabolic response to resistance exercise and essential amino acids is delayed with aging. J Appl Physiol 104:1452-1461

Garlick PJ, Maltin CA, Baillie AG, Delday MI, Grubb DA (1989) Fiber-type composition of nine rat muscles. II. Relationship to protein turnover. Am J Physiol 257:E828-E832

Greenhaff PL, Karagounis LG, Peirce N, Simpson EJ, Hazell M, Layfield R, Wackerhage H, Smith K, Atherton P, Selby A, Rennie MJ (2008) Disassociation between the effects of amino acids and insulin on signaling, ubiquitin ligases, and protein turnover in human muscle. Am J Physiol Endocrinol Metab 295:E595-E604

Koopman R, Wagenmakers AJ, Manders RJ, Zorenc AH, Senden JM, Gorselink M, Keizer HA, van Loon LJ (2005) Combined ingestion of protein and free leucine with carbohydrate increases postexercise muscle protein synthesis in vivo in male subjects. Am J Physiol Endocrinol Metab 288:E645-E653

Koopman R, Manders RJ, Jonkers RA, Hul GB, Kuipers H, van Loon LJ (2006a) Intramyocellular lipid and glycogen content are reduced following resistance exercise in untrained healthy males. Eur J Appl Physiol 96:525-534

Koopman R, Verdijk LB, Manders RJF, Gijsen AP, Gorselink M, Pijpers E, Wagenmakers AJM, van Loon LJC (2006b) Coingestion of protein and leucine stimulates muscle protein synthesis rates to the same extent in young and elderly lean men. Am J Clin Nutr 84:623-632

Koopman R, Zorenc AH, Gransier RJ, Cameron-Smith D, van Loon LJ (2006c) The increase in S6K1 phosphorylation in human skeletal muscle following resistance exercise occurs mainly in type II muscle fibers. Am J Physiol Endocrinol Metab 290:E1245-E1252

Koopman R, Beelen M, Stellingwerff T, Pennings B, Saris WH, Kies AK, Kuipers H, van Loon LJ (2007a) Co-ingestion of carbohydrate with protein does not further augment post-exercise muscle protein synthesis. Am J Physiol Endocrinol Metab 293:E833E842

Koopman R, Pennings B, Zorenc AH, van Loon LJ (2007b) Protein ingestion further augments S6K1 phosphorylation in skeletal muscle following resistance type exercise in males. J Nutr 137:1836-1842

Koopman R, Verdijk LB, Beelen M, Gorselink M, Kruseman AN, Wagenmakers AJ, Kuipers H, van Loon LJ (2008) Co-ingestion of leucine with protein does not further augment post-exercise muscle protein synthesis rates in elderly men. Br J Nutr 99:571-580

Koopman R, Crombach N, Gijsen AP, Walrand S, Fauquant J, Kies AK, Lemosquet S, Saris WH, Boirie Y, Van Loon LJ (2009) Ingestion of a protein hydrolysate is accompanied by an accelerated in vivo digestion and absorption rate when compared with its intact protein. Am J Clin Nutr 90:106-115

Kraemer WJ, Fry AC (1995) Strength testing; development and evaluation of methodology. In: Maud PJ, Foster C (eds) Physiological assessment of human fitness. Human Kinetics, Leeds, pp 115-133

Kumar V, Selby A, Rankin D, Patel R, Atherton P, Hildebrandt W, Williams J, Smith K, Seynnes O, Hiscock N, Rennie MJ (2009) Age-related differences in the dose-response relationship of 
muscle protein synthesis to resistance exercise in young and old men. J Physiol 587:211-217

Mabuchi K, Sreter FA (1980a) Actomyosin ATPase. I. Quantitative measurement of activity in cryostat sections. Muscle Nerve 3:227-232

Mabuchi K, Sreter FA (1980b) Actomyosin ATPase. II. Fiber typing by histochemical ATPase reaction. Muscle Nerve 3:233-239

MacDougall JD, Tarnopolsky MA, Chesley A, Atkinson SA (1992) Changes in muscle protein synthesis following heavy resistance exercise in humans: a pilot study. Acta Physiol Scand 146:403-404

Mittendorfer B, Andersen JL, Plomgaard P, Saltin B, Babraj JA, Smith K, Rennie MJ (2005) Protein synthesis rates in human muscles: neither anatomical location nor fibre-type composition are major determinants. J Physiol 563:203-211

Parkington JD, Siebert AP, LeBrasseur NK, Fielding RA (2003) Differential activation of mTOR signaling by contractile activity in skeletal muscle. Am J Physiol Regul Integr Comp Physiol 285:R1086-R1090

Phillips SM, Tipton KD, Aarsland A, Wolf SE, Wolfe RR (1997) Mixed muscle protein synthesis and breakdown after resistance exercise in humans. Am J Physiol 273:E99-E107

Rennie MJ, Edwards RH, Halliday D, Matthews DE, Wolman SL, Millward DJ (1982) Muscle protein synthesis measured by stable isotope techniques in man: the effects of feeding and fasting. Clin Sci (Lond) 63:519-523

Rennie MJ, Bohé J, Wolfe RR (2002) Latency, duration and dose response relationships of amino acid effects on human muscle protein synthesis. J Nutr 132:3225S-3227S

Sakamoto K, Aschenbach WG, Hirshman MF, Goodyear LJ (2003) Akt signaling in skeletal muscle: regulation by exercise and passive stretch. Am J Physiol Endocrinol Metab 285:E1081E1088
Sakamoto K, Goransson O, Hardie DG, Alessi DR (2004) Activity of LKB1 and AMPK-related kinases in skeletal muscle: effects of contraction, phenformin, and AICAR. Am J Physiol Endocrinol Metab 287:E310-E317

Tang JE, Perco JG, Moore DR, Wilkinson SB, Phillips SM (2008) Resistance training alters the response of fed state mixed muscle protein synthesis in young men. Am J Physiol Regul Integr Comp Physiol 294:R172-R178

Tannerstedt J, Apro W, Blomstrand E (2009) Maximal lengthening contractions induce different signaling responses in the type I and type II fibers of human skeletal muscle. J Appl Physiol 106:1412-1418

Trappe TA, Raue U, Tesch PA (2004) Human soleus muscle protein synthesis following resistance exercise. Acta Physiol Scand 182:189-196

Verdijk LB, Gleeson BG, Jonkers RA, Meijer K, Savelberg HH, Dendale P, van Loon LJ (2009) Skeletal muscle hypertrophy following resistance training is accompanied by a fiber typespecific increase in satellite cell content in elderly men. J Gerontol A Biol Sci Med Sci 64:332-339

Wilkinson SB, Phillips SM, Atherton PJ, Patel R, Yarasheski KE, Tarnopolsky MA, Rennie MJ (2008) Differential effects of resistance and endurance exercise in the fed state on signalling molecule phosphorylation and protein synthesis in human muscle. J Physiol 586:3701-3717

Wojtaszewski JF, MacDonald C, Nielsen JN, Hellsten Y, Hardie DG, Kemp BE, Kiens B, Richter EA (2003) Regulation of 5'AMPactivated protein kinase activity and substrate utilization in exercising human skeletal muscle. Am J Physiol Endocrinol Metab 284:E813-E822 